\title{
Hereditary Hematologic Disorders in Najaf Province-Iraq
}

Hussein Kadhem Al-Hakeim ${ }^{\text {a }}$, Ammar Kadhum Abdulla ${ }^{\text {, }}$, Abbas F. Almulla ${ }^{\mathrm{c}}$, Michael Maes d,e,f

a Department of Chemistry, College of Science, University of Kufa, Iraq. E-mail: headm2010@yahoo.com.

b Department of Chemistry, College of Science, University of Kufa, Iraq. E-mail: godofwaruv@gmail.com.

${ }^{c}$ Medical Laboratory Technology Department, College of Medical Technology, The Islamic University, Najaf, Iraq E-mail: abbass.chem.almulla1991@gmail.com.

${ }^{\mathrm{d}}$ Department of Psychiatry, Faculty of Medicine, Chulalongkorn

University, Bangkok, Thailand. E-mail: dr.michaelmaes@ hotmail.com.

${ }^{\mathrm{e}}$ Department of Psychiatry, Medical University of Plovdiv, Plovdiv, Bulgaria;

${ }^{\mathrm{f}}$ School of Medicine, IMPACT Strategic Research Centre, Deakin University, Australia. Email: dr.michaelmaes@hotmail.com.

Corresponding Author: Prof. Dr. Hussein Kadhem Al-Hakeim, University of Kufa, Najaf, Iraq. E-mail: headm2010@yahoo.com. 


\begin{abstract}
Background: Hereditary hematologic disorders (HHDs) originate from genetic factors that cause disruptions of blood homeostasis. The Thalassemia Unit, Najaf province, Iraq, keeps all medical records of all patients with HHD from the Najaf province.

Objectives: We aimed to conduct an epidemiological study to obtain a comprehensive epidemiological picture with regard to sex distribution, and effects of blood groups and consanguinity.
\end{abstract}

Patients and methods: All registered HHD patients (until May 2019) in the Thalassemia Unit (1122 patients, aged 0.5-65 years old) were included in the study.

Results: The prevalence of HHD in Najaf city is 75.6 per 100,000 population. The number of patients registered as new patients is increasing over the years. There are significantly more male than female HHD patients (Male $=54.37 \%$, Female $=45.63 \%, \mathrm{p}=0.023$ ). The top 3 prevalent HHD are Major thalassemia (33.15\%), intermediate thalassemia (31.91\%), and Thalassemia+Sickle (12.65\%). The highest percentage of patients were in the center of Najaf (56.42\%) followed by Kufa, Mishkhab, Haidariah, Manathera, and Abbasiya. The distribution of blood groups and Rh factors of HHD patients in the Najaf population was not significantly different from that in the normal population. The consanguinity rate observed in our patients' parents $(78.24 \%)$ was significantly higher $(\mathrm{p}<0.0001)$ as compared with the consanguinity rate in the population $(45.8 \%)$.

Conclusions: During the last few years, there was an increase in HHD cases in Najaf city and, therefore, there is an urgent need to increase awareness about the effects of consanguinity marriages on HHD in order to limit the incidence of HHD. 
Keywords: Hereditary hematological disorder, Najaf, thalassemia, epidemiology, and consanguinity. 


\section{Introduction}

Hereditary hematologic disorders (HHD) refer to the medical conditions that affect the blood (or its components) to work properly. HHD may result from disorders in the bone marrow and the fatty area inside the bones that produces new red blood cells, white blood cells, and platelets (1). Thalassemia is one of the genetic HHD and is one of the most widespread genetic diseases in the world with a particularly high frequency in tropical and sub-tropical areas such as Mediterranean countries, the Indian subcontinent, the Middle East, North Africa and Southeast Asia (2). Thalassemia defined as a varied group of inherited disorders, occurs due to genetic mutations disturbing the globin chain of the hemoglobin $(\mathrm{Hb})$ tetramer $(3)$. The primary defect is usually quantitative, consisting of a reduced or absent synthesis of normal globin chains (4). Based on genetic factors, thalassemia can be classified into $\alpha, \beta, \gamma, \delta$, $\delta \beta$, and $\varepsilon \gamma \delta \beta$ forms depending on which globin is under-produced and based on clinical features, thalassemia is classified into $\beta$-thalassemia major $(\beta$-TM), $\beta$-thalassemia intermedia $(\beta$-TI) and $\beta$-thalassemia minor (5). The majority of the fetus with $\alpha$-thalassemia will die in utero or shortly after birth, while patients with $\beta$-thalassemia will die before 5 years of age if not treated with regular transfusions, iron chelation therapy or hematopoietic stem cell transplantation (6).

Beta-thalassemia is an autosomal recessive disorder that affects the $\beta$-globin gene of the hemoglobin with considerable predominance among other types of thalassemia. Most of the patients with $\beta$-thal suffer severe anemia and grave complications including liver damage, cardiac disease and endocrine dysfunction (7). Moreover, patients with major thalassemia impose a considerable burden on their families and health authorities. The number of people worldwide who have abnormal hemoglobin and thalassemia is estimated to be 270 million, 80 of which are carriers of $\beta$-thalassemia. Modern reviews indicate that among 300,000 and 
400,000 babies are born with a serious hemoglobin disorder each year $(23,000$ with $\beta$ thalassemia major) and that up to $90 \%$ of these births occur in low- or middle-income countries (8). Studies have suggested that poverty, consanguinity, and unawareness about the disease are the prominent factors in increasing the prevalence of this genetic disorder (9). Conservative estimates suggest that at least $5.2 \%$ of the world's population (over 360 million) carry a significant hemoglobin variant and there are more than 100 million $\beta$-thalassemia carriers, with a global prevalence of $1.5 \%(10,11)$.

Sickle cell anemia is a genetic red blood cell disorder which is a result of a mutation in the hemoglobin encoding gene namely the substitution of Valine into Glutamine at the sixth position of the beta chain of hemoglobin (12). In Africa, Asia, and the Middle East, Sickle cell anemia is widely distributed (12). The global meta-estimate for the birth prevalence of homozygous sickle cell disease was $0.112 \%$, while in Africa birth prevalence up to $1.125 \%$ compared with Europe $0.043 \%$ (13). The experience of the disease is unique for individuals with double recessive genes of sickle cell (ss homozygote), in contrast, people with heterozygotes (AS) are referred to as carriers which are asymptomatic and generally not aware of the diseased gene, they carry (12).

Bone marrow failure (BMF) is the discontinuation or reduction in the production of blood cells affecting one or more cell lines. A reduction in the numbers of circulating red blood cells (RBCs), white blood cells (WBCs), and platelets are manifestations in most BMF cases, particularly in severe or advanced stages (14). BMF is most often inherited in an autosomal recessive manner while also a small subset is inherited in an X-linked recessive pattern (15). There are triphasic peaks for BMF at 2 to 5 years (inherited is most common), between 20 to 25 years, and after 65 years (most likely due to acquired causes). The majority of children with 
inherited bone marrow failures have an identifiable cause (75\%) (15). The most common inherited bone marrow failure, namely Fanconi anemia, occurs in 1 to 5 cases per million with a carrier frequency of 1 in 200 to 300 (16). Nevertheless, there are insufficient epidemiological data on the sex and age distribution, and consanguinity issues associated with thalassemia in the Najaf province of Iraq. Hence, the present study aimed to conduct an epidemiological study to examine these factors in all patients with genetic HHD in Najaf province-Iraq.

\section{Participants and Methods}

\section{Participants}

In the current study, 1122 patients with HHD have been included, all data of the participants were recorded after taken their approval or consent from their parents. There is a sex difference among participants in this study with 512 females and 610 males. The patient's data were collected from the thalassemia center in the Al-Zahraa hospital in the Najaf province, most of the patients were within the same city namely Najaf province, the rest of them from other districts of Najaf and few of them from other cities. A wide range of ages (less than 1 year- 65 years) was recorded in those patients. All other required data have been taken from patients directly or transferred from the records of the patients in the center. The data were collected between the date 10/2019-03/2020.

\section{Statistical analysis}

Descriptive statistics (mean \pm standard deviation), frequencies or ratios were used to evaluate the characteristics of the patients. The student t-test was used to compare the results 
of the subjects. A Chi-square test (goodness of fit test) was used to examine whether the distribution of patients into a nominal variable follows the known distribution. Statistical tests were 2-tailed and a p-value of 0.05 was used for statistical significance. All statistical analyses were performed using IBM SPSS windows version 25, 2017.

\section{Results}

\section{$\underline{\text { 1-Overall Hematologic Disorders in Najaf Province }}$}

Table 1 shows the types and distribution of the HHD in Najaf province. Most of the patients are affected with major thalassemia and intermediate thalassemia among other HHD, fewer patients suffered from thalassemia+sickle and less were affected with sickle cell anemia, whereas others have other types of HHD. Most of the patients with major thalassemia are living within the center of Najaf then in Kufa city center.

\section{2- Gender distribution of patients with HHD in Najaf province}

Table 2 shows the gender differences in patients with HHD. There is a significant difference $(\mathrm{p}<0.001)$ among males and females in the rate of unknown bleeding tendency. The sex distribution of men and women with HHD was significantly different from the known sex distribution of the population (male to female ratio 1.04:1) in Najaf city. The latter data were obtained from the results of the Iraqi Central Statistical Organization census held in 2018 that showed a male sex ratio of $50.98 \%$ versus $49.02 \%$ (17).

\section{3- The distributions of the blood groups of patients with HHD in Najaf province.}

In Table 3, most of the patients with HHD belong to the positive groups of blood, and the $\mathrm{O}$ blood group followed by $\mathrm{A}, \mathrm{B}$, and $\mathrm{AB}$. The data in HHD patients were compared with 
the know blood group and $\mathrm{Rh}$ factor distribution in Najaf Community (18) and altered by a systemic survey carried out by (19). Those results were: $\mathrm{A}=31.61 \%, \mathrm{~B}=24.08 \%, \mathrm{O}=37.78 \%$, $\mathrm{AB}=6.54, \mathrm{Rh}(+)=91.06 \%$, and $\mathrm{Rh}(-)=8.93 \%$. We found no statistically significant differences either in the distribution of the blood groups $\left(\chi^{2}=0.038, \mathrm{p}=0.998\right)$ or $\mathrm{Rh}$ groups $\left(\chi^{2}=1.819\right.$, $\mathrm{p}=0.177$ ) as compared with the normal population distribution

\section{4- Age distribution of the patients with HHD}

The age distribution of major HHDs was plotted for each disease as frequency figures. The overall age distribution of all patients with HHD in addition to the major individual diseases is shown in Table 4. The results indicated that the majority of the patients were aged 5 and 10 years also many cases with HHD were concentrated below 20 years old. The table illustrates the frequency of the $\beta$-TM across the age of the patients, as the table displayed the majority of the patients were aged 5 followed by 10 and 15 years old and only a few cases distributed around the other age ranges. The distribution of patients with BMF showed that most BMF cases were in early their life (below 5 years) followed with fewer cases at age 10 years old. The same distribution was found in intermediate thalassemia patients where the majority of cases were found in childhood (less than 10 years old). The majority of sickle thalassemia patients were less than 5 years old. Most cases are detected in the first decade of life, and rarely in adults and elderly people. While the older age distribution noticed were in sickle cell anemia where most of the patients were below 20 years, and few cases are above 20 years old.

\section{5- Number of patients over the years}


The number of new HHD cases registered in the Thalassemia Unit in Najaf city are plotted in Figure 1 at intervals of three years each. The results showed an increase in the number of new cases with time and a peak in the last three years.

\section{6-Distribution of Consanguinity among HHD patient's parents}

The consanguinity rates of the parents of patients with major HHD are plotted in Figure 2. The ratio is high (78.24\%) among parents of HHD patients. For comparison with consanguinity rates among the whole Iraqi population, we used the WHO report which showed that the range of consanguinity (cousin marriage) is $31.8 \%-45.8 \%$ with median $=37.8 \%$ (20). The consanguinity rate observed in our patients' parents was significantly increased $\left(\chi^{2}=122.979\right.$, $\mathrm{p}<0.0001$ ) as compared with the consanguinity in the population (based on the median $37.8 \%$ value). We have no official report about the consanguinity rate in Najaf city and therefore we also used the upper $45.8 \%$ rate reported by the WHO and found a significant increase $\left(\chi^{2}=261.5, \mathrm{p}<0.0001\right)$ in our patients' parent's consanguinity rate.

\section{Discussion}

HHD occurs all over the world, particularly in some geographical areas there is a high prevalence of these disorders. Here, we studied the prevalence of HHD in Najaf city, which has a center for recording and treatment of HHD patients due to the importance of such public health problems in several parts of Iraq. Taking into account the number of patients and the whole population, the prevalence of HHD in Najaf city is 75.6 per 100,000 people. The total annual incidence of symptomatic HHDs is estimated to be $1 / 100,000$ worldwide and 10/100,000 in the European Union (21). The thalassemia major and intermediate subtypes are the most prevalent HHDs in Najaf city. Major thalassemia, intermediate thalassemia, and 
thlassemia+Sickle disease comprise $77.71 \%$ of all HHD cases. $\beta$-thalassemia is the most frequent disease, followed by intermediate thalassemia and thalassemia with the sickle, whereas other types of HHD have a lower prevalence in Najaf province. In other studies, sex differences in hemoglobinopathies have been detected, where $\beta$-thalassemia heterozygous (trait) was the most frequently encountered hemoglobinopathy (17.64\%) and $\beta$-thalassemia homozygous (major and intermediate) was $2.92 \%(22)$.

Thalassemia occurs in approximately 44 of every 100,000 live births worldwide (23). Thalassemia is also prevalent in other countries among other types of HHD $(2,22)$. Globally the inherited $\beta$-thalassemias are the most frequent single-gene disorders (10) and the most common chronic hemolytic anemia among children and adolescents worldwide (24). Also in areas with malaria like Africa, Mediterranean countries, the Middle East, the Indian subcontinent, and Southeast Asia, $\beta$-Thalassemia is most prevalent (25). Among types of thalassemia, there is a huge diversity all over different countries, for example in UAE $(3 \% \alpha-$ thalassemia and 2.40\% $\beta$-thalassemia) (26), Qatar (28\% $\alpha$ thalassemia and 17\% $\beta$-thalassemia) (27), and Jordan (3.3\% $\alpha$-thalassemia and 3.5\% $\beta$-thalassemia) (28).

We did not observe significant differences in sex distribution (in comparison with the sex distribution of the Najaf population) in the major HHD. Our results show that there was no significant difference among males and females in $\beta$-thalassemia, intermediate thalassemia, thalassemia+Sickle, minor thalassemia, and hemophilia. Other studies showed also no significant difference in sex ratios between controls and HHD (29). In an important study, thalassemia affected males and females equally and occurs in approximately 44/100,000 live births $(23,30)$. A non-statistically significant difference was observed between male $(53.5 \%)$ 
and female (46.5\%) thalassemia patients (31). Nevertheless, other studies reported significant sex differences in the prevalence of the disease. For example, studies conducted in India displayed a slight male predominance $(53.2 \%)$ with a male to female ratio of $1.14: 1$ (32) and there were also more males than females in bleeding tendency $(n=15, p=0.049)$, unexplained anemia $(n=11, p<0.001)$, hemophilia $(n=6, p<0.001)$, and immune hemolysis $(n=2, p=0.024)$. Monhal et al (2012) (22) and Khan et al. found that hemoglobinopathies are more prevalent among males than females (33). Furthermore, Nasab (1979) reported an excess of males among $140 \beta$-thal patients in the same geographic area (34) and suggested that this excess might be due to more concern of villagers about the health of their male offspring (31). The same excess of males over females was reported in Bangladesh reporting a male to female ratio of 1.26 (35). In the current study, there was no significant difference among males and females in the prevalence of bone marrow failure (BMF) and unexplained anemia while previous studies showed a male preponderance in patients with $\mathrm{BMF}$ and unexplained anemia $(36,37)$.

We observed that blood groups and $\mathrm{Rh}$ factor's distributions were not statistically different between HHD patients and the Najaf population. The overall age distribution of HHD patients in Najaf province showed that the highest prevalence of HHDs lies between 5 to 10 years old. Furthermore, the cumulative sum indicated that most patients were below 20 years old. All cases of HHD reported in this study started at an early age, as was expected (2). Our results were similar to many previous studies, whereas investigation regarding the Beta thalassemia found that the mean age of patients was $7.68 \pm 5.8$ years. About one-third (33\%) of the cases were in the age group 7-10 years, followed by the age group 3-6 years. This result is in agreement with Bejaoui and Guirat reporting a median age of 10.7 years among thalassemic patients in Tunisia $(35,38)$. In contrast to these results, in 2016, lower mean age of 3.7 years 
was reported in a similar study carried out in India. The best outcome of thalassemia was among those patients 1.7 years old or younger at the time of diagnosis and those patients 2 years old or younger at first blood transfusion (39). Other disorders also showed the major part of patients' age lies below 5 years old including bone marrow failure, intermediate thalassemia, and sickle-thalassemia. While the highest number of sickle cell anemia patients are lies between 5-15 years old. These results revealed a difference in the age of appearance of the severer symptoms depending on the type of disease.

The results showed an increase in the number of new HHD cases registered in the Thalassemia Unit in Najaf city during the last three years of the study, namely 2015-2018. There is only a slight decrease in the new case registration between 2012-2015 which is involved in the peak of terrorism operations in all the Iraqi areas. Whether this is the reason or not needs to be investigated.

Most importantly, our results show a highly increased frequency of close family members' marriages, most often cousins, in patients with HHD (78.24\%) as compared with the expected consanguinity rate of $45.8 \%$. One study, conducted in Tunisia, reported a consanguinity rate of $75.3 \%$ among the patients' parents (38). Another study reported that $40.6 \%$ of $\beta$-thal patients occurred in the offspring of first-cousin marriages (31). Positive parent consanguinity was found in around two-thirds of the studied cases (74.2\%). This is important as most of them $(64.2 \%)$ are first-degree relatives while thalassemia is transmitted in an autosomal recessive manner and a high consanguinity rate is a distinguishing feature of the disease (32). In 2010, the hemoglobinopathies patients in the thalassemia center in the Al-Muthana population, 96.66\% were offspring from consanguinity marriages (40) and in Thi-Qar this was $67.5 \%$ (41). 
After six years, about $77.56 \%$ of the $\beta$-thalassemia patients were offspring of consanguinity marriage from the first-degree cousins (42).

Among Iraqis, the frequency of consanguineous marriages was higher among parents of children with congenital malformations compared to the general population $(43,44)$. In our hospital, $70.2 \%$ of children with an adverse fetal outcome were offspring of consanguinity marriages (45). Recently, it is found that the incidence of congenital abnormalities was $23.2 \%$ in newborns from consanguineous parents versus $7.1 \%$ in non-consanguineous parents (46). In another study, $70.13 \%$ of mothers of babies delivered with congenital anomalies had a history of consanguinity (47). The consanguinity was found in $76.95 \%$ of the families studied inherited bleeding disorders in Iraq (48).

Thalassemia is highly concentrated in small towns where the consanguinity between relatives is more predominant and marrying close family members is a tradition in many countries including Iraq, leading to higher rates of genetic disorders (49). The latter investigation also reported that the frequency of genetic disorders among such children is around twice that in children of non-related parents $(50,51)$. One billion people worldwide live in countries where marriage among relatives is common. Of this billion, one in three is married to a second cousin or closer relative or is the progeny of such a marriage $(50,51)$. In Iraq, the consanguinity is still widely spread and predominant (52) and some areas showed consanguinity in around $60 \%$ of all marriages (53). A WHO report showed that the range of consanguinity (cousin marriage) is $31.8-45.8 \%$ with a median $=37.8 \%$ (20). For example, the consanguinity marriages distribution of two provinces in the middle Euphrates area (surrounding Najaf province) was $43.5 \%$ in Al-Qadisisya province and $56.4 \%$ in Babylon province (54). In Kirkuk, north of Iraq, the percentage of consanguinity marriage among the 
parents of the HHD patients was $89-92.7 \%$ including $43-44.7 \%$ for first-cousin marriage origin (55). Unrelated couples show a lower incidence of the disease than consanguineous marriages (33). As such, the increased incidence of thalassemias may be attributed to an increased rate of consanguineous marriages (38). Therefore, it is important to avoid consanguineous marriages to limit the incidence of thalassemia disease (56).

\section{Conclusion}

This study shows the frequency of HHD in Najaf province, Iraq. The first finding of this study is that thalassemia is the more common disorder in this area with $\beta$-thal showing the highest ratio. The second major finding is that the increased cases for HHD are due to the high rate of the consanguinity marriage and it is important to avoid this tradition not only in Iraq only but also worldwide.

\section{References}

1. Arboix A, Jimenez C, Massons J, Parra O, Besses C. Hematological disorders: a commonly unrecognized cause of acute stroke. Expert Rev Hematol. 2016;9:891-901.

2. Lai K, Huang G, Su L, He Y. The prevalence of thalassemia in mainland China: evidence from epidemiological surveys. Sci Rep. 2017;7:920.

3. Shawky RM, Kamal TM. Thalassemia intermedia: An overview. Egyptian Journal of Medical Human Genetics. 2012;13:245-255.

4. Borgna-Pignatti C, Galanello R: Thalassemias and related disorders: quantitative disorders of hemoglobin synthesis. Wintrobe's Clinical Hematology. Philadelphia: Lippincott Williams \& Wilkins; 2003.

5. Weatherall DJ, Clegg JB: The thalassaemia syndromes, John Wiley \& Sons; 2008.

6. Pan HF, Long GF, Li Q, Feng YN, Lei ZY, Wei HW, Huang YY, Huang JH, Lin N, Xu QQ, Ling SY, Chen $\mathrm{XJ}$, Huang T. Current status of thalassemia in minority populations in Guangxi, China. Clin Genet. 2007;71:419-426.

7. Kurtoglu AU, Kurtoglu E, Temizkan AK. Effect of iron overload on endocrinopathies in patients with beta-thalassaemia major and intermedia. Endokrynol Pol. 2012;63:260-263.

8. De Sanctis V, Kattamis C, Canatan D, Soliman AT, Elsedfy H, Karimi M, Daar S, Wali Y, Yassin M, Soliman N, Sobti P, Al Jaouni S, El Kholy M, Fiscina B, Angastiniotis M. beta-Thalassemia Distribution 
in the Old World: an Ancient Disease Seen from a Historical Standpoint. Mediterr J Hematol Infect Dis. 2017;9:e2017018.

9. Ghani R, Saboor M, Ahmed I, Mushtaq S. dentification of $\beta$-globin gene mutations in families and the affected child with $\beta$ thalassemia major: Importance of prenatal diagnosis. . Access Int J.

2013;1:45-50.

10. Modell B, Darlison M. Global epidemiology of haemoglobin disorders and derived service indicators. Bulletin of the World Health Organization. 2008;86:480-487.

11. Colah R, Gorakshakar A, Nadkarni A. Global burden, distribution and prevention of $\beta$ thalassemias and hemoglobin E disorders. Expert Review of Hematology. 2010;3:103-117.

12. Singh A, Goli VB, Mohanty B, Sunder A. Sickle Cell Anemia: An Overview of the Neglected Blood Disorder. Integrative Journal of Global Health. 2017;1.

13. Wastnedge E, Waters D, Patel S, Morrison K, Goh MY, Adeloye D, Rudan I. The global burden of sickle cell disease in children under five years of age: a systematic review and meta-analysis. J Glob Health. 2018;8:021103.

14. Shimamura A, Alter BP. Pathophysiology and management of inherited bone marrow failure syndromes. Blood Rev. 2010;24:101-122.

15. Fassel H, Sheth S. Bone Marrow Failure in Children: Approach to Diagnosis and Treatment. Indian J Pediatr. 2020;87:141-149.

16. Giri N, Stratton P, Savage SA, Alter BP. Pregnancies in patients with inherited bone marrow failure syndromes in the $\mathrm{NCl}$ cohort. Blood. 2017;130:1674-1676.

17. CSO CSO: Statistical brief of Najaf, 2018. . Ministry of planning, Iraq

2018. pp. http://cosit.gov.iq/ar/?option=com content\&view=article\&layout=edit\&id=1219

18. Al-Shamma YM. The association of bronchial asthma to (ABO) blood groups in Najaf governorate. KUFA MEDICAL JOURNAL. 2008;11:234-245.

19. Haider SK, Al-Maliki AHA-A. Normal distribution of ABO blood group and Rhesus factor in AlNajaf province. European Journal of Experimental Biology. 2015;5:18-21.

20. WHO. Iraqi family health survey report (IFHS)1-65. http://wwwemrowhoint/dsaf/EMRPUB 2009 EN 1367pdf?ua=1 2006.

21. Galanello R, Origa R. Beta-thalassemia. Orphanet journal of rare diseases. 2010;5:11.

22. Mondal B, Mait S, Biswas BK, Ghosh D, Paul S. Prevalence of hemoglobinopathy, $A B O$ and rhesus blood groups in rural areas of West Bengal, India. J Res Med Sci. 2012;17:772-776.

23. Hamidi Z: What We Learn from Bone Complications in Congenital Diseases? Thalassemia, an Example, INTECH Open Access Publisher; 2012.

24. Cassinerio E, Roghi A, Pedrotti P, Brevi F, Zanaboni L, Graziadei G, Pattoneri P, Milazzo A, Cappellini MD. Cardiac iron removal and functional cardiac improvement by different iron chelation regimens in thalassemia major patients. Annals of hematology. 2012;91:1443-1449.

25. Weatherall D. The inherited diseases of hemoglobin are an emerging global health burden. Blood. 2010;115:4331-4336.

26. Baysal E. Molecular basis of $\beta$-thalassemia in the United Arab Emirates. Hemoglobin.

2011;35:581-588.

27. Tremblay C, Hamilton B, Sala M, Paoloni J, Chalabi H. Prevalence of haemoglobinopathy in sportsmen in qatar. British Journal of Sports Medicine. 2011;45:317-317.

28. Abu-Ghoush Mw. Subtypes of alpha thalassemia diagnosed at a Medical Center in Jordan. TAFPreventive Medicine Bulletin. 2008;7:373.

29. Al-Asadi ZMA. HAEMATOLOGICAL STUDY OF $\Omega$-THALASSAEMIA AMONG IRAQI POPULATION Iraqi J Biotechnol. 2008;7:186-197. 
30. Muncie Jr H. Campbell J. a and b thalassemia. Am Fam Physician. 2009;80:339-344.

31. Asadi-Pooya AA, Doroudchi M. Thalassemia major and consanguinity in Shiraz city, Iran. Turk J Haematol. 2004;21:127-130.

32. Al-Kherbash $\mathrm{H}, \mathrm{Al}$-Awdi A, Hasan N. Pattern and clinical profile of thalassemia among pediatric patients attending the Yemeni Society Centers for Thalassemia and Genetic Blood Disorders in Yemen. The Scientific Journal of Al-Azhar Medical Faculty, Girls. 2017;1.

33. Khan MS, Ahmed M, Khan RA, Mushtaq N, Shah MWU. Consanguinity ratio in b-thalassemia major patients in District Bannu. J Pak Med Assoc. 2015;65:1161-1163.

34. Nasab AH. Clinical and laboratory findings in the initial diagnosis of homozygous beta thalassaemia in Fars Province, Iran. British journal of haematology. 1979;43:57-61.

35. Hossain MS, Raheem E, Sultana TA, Ferdous S, Nahar N, Islam S, Arifuzzaman M, Razzaque MA, Alam R, Aziz S, Khatun H, Rahim A, Morshed M. Thalassemias in South Asia: clinical lessons learnt from Bangladesh. Orphanet J Rare Dis. 2017;12:93.

36. Grimaldi F, Gandhi S, Risitano AM: Epidemiology of Acquired Bone Marrow Failure. in Congenital and Acquired Bone Marrow Failure2017. pp. 1-11.

37. Artz AS, Thirman MJ. Unexplained anemia predominates despite an intensive evaluation in a racially diverse cohort of older adults from a referral anemia clinic. J Gerontol A Biol Sci Med Sci. 2011;66:925-932.

38. Bejaoui M, Guirat N. Beta thalassemia major in a developing country: epidemiological, clinical and evolutionary aspects. Mediterr J Hematol Infect Dis. 2013;5:e2013002.

39. Al-Kherbash HA, Al-Awdi A, Hasan NS. Pattern and clinical profile of thalassemia among pediatric patients attending the Yemeni Society Centers for Thalassemia and Genetic Blood Disorders in Yemen. The Scientific Journal of Al-Azhar Medical Faculty, Girls. 2017;1:43.

40. Fadil Abass A. Haemogloin Level, Blood Group, Chest X Ray Findings and Consanguinity in Thalassemic Children in AL Muthana Governorate. Al-Kindy College Medical Journal 2013;9:53-56. 41. Abbas YT, SJ; Al-Husainin, KR. [Laboratory and clinical study of thalassemia patients at Thi-Qar governorate]. AL-TAQANI 2010;23:A1-A7.

42. Tawfeeq AA. A Prospective Study for the Outcomes of Thalassemia in Kirkuk 2016 Kirkuk University Journal for Scientific Studies 2017;12:140-156.

43. Mahdi A. Consanguinity and its effect on major congenital malformations. Iraqi Med J. 1992;40:170-176.

44. Hamamy HA, Al-Hakkak ZS. Consanguinity and reproductive health in Iraq. Human heredity. 1989;39:271-275.

45. Anwar NaA, H. Consanguinity and Adverse Fetal Outcome. Proceedings of RCOG World Congress 2014 , India. 2014; Labour \& Obstetric Complications Session:Poster number 516.

46. Sijal Fadhil Farhood A-J, Ehab Raad Abbas a-S, Ameer Kadhum Hussein A-H, Hadeel Fadhil Farhood A-J, Ashraf Mohammed Ali H. A Study of the Association of Parental Consanguinity with Birth Defects and Neonatal Medical Problems in Babylon Province. Journal of University of Babylon 2018;26:143-153.

47. alaarji Kk. Risk factors of congenital anomalies in Karbala Al-Qadisiyah Medical Journal 2017;13:23-29.

48. Al-Rahal NK. Inherited Bleeding Disorders in Iraq and Consanguineous Marriage. Int J Hematol Oncol Stem Cell Res. 2018;12:273-281.

49. Merten M. Keeping it in the family: consanguineous marriage and genetic disorders, from Islamabad to Bradford. BMJ: British Medical Journal (Online). 2019;365.

50. Hamamy H. Consanguineous marriages: preconception consultation in primary health care settings. . J Community Genet 2012;3:185-192. 
51. Mobarak AM, Chaudhry T, Brown J, Zelenska T, Khan MN, Chaudry S, Wajid RA, Bittles AH, Li S. Estimating the health and socioeconomic effects of cousin marriage in South Asia. Journal of biosocial science. 2019;51:418-435.

52. Tadmouri GO, Nair P, Obeid T, Al Ali MT, Al Khaja N, Hamamy HA. Consanguinity and reproductive health among Arabs. Reproductive health. 2009;6:17.

53. Khalid M: Iraq Living Conditions Survey 2004. United Nations Development Programme Website:< htp://www. iq. undp. org/ILCS ...; 2011.

54. AL-Rekaby HRM. Consanguinity marriage and fertility outcome healthin the middle Euphrates of Iraq. J THI-QAR SCI. 2008;1:29-34.

55. Ibraheem SA-J. Genetic of thalassemia intermediate in Kirkuk ethnic groups Tikrit Journal of Pure Science 2010;15:1-4.

56. Saeed U, Piracha ZZ. Thalassemia: impact of consanguineous marriages on most prevalent monogenic disorders of humans. Asian Pacific Journal of Tropical Disease. 2016;6:837-840. 
Legends:

Table 1: Overall Hematologic Disorders in the major areas in Najaf province

Table 2: Gender distribution of HHD patients in Najaf province.

Table 3: Blood group distribution of HHD patients in Najaf province.

Table 4: The age distribution of all HHD patients in addition to major subgroups in Najaf province.

Figure 1: The total number of patients registered in the Thalassemia Unit-Najaf over the years from 2003 till the end of 2018.

Figure 2: Consanguinity among patients with HHD in Najaf Province 
Table 1: Overall Hematologic Disorders in the major areas in Najaf province

\begin{tabular}{|l|c|c|c|c|c|c|c|c|c|}
\hline HHD & $\begin{array}{c}\text { Najaf } \\
\text { Center }\end{array}$ & Kufa & Mishkhab & Manathera & Abbasiya & Haidariah & $\begin{array}{c}\text { Other } \\
\text { cities }\end{array}$ & Total & $\begin{array}{c}\text { \% of total } \\
\text { disorders }\end{array}$ \\
\hline Major thalassemia & 207 & 55 & 58 & 20 & 23 & 6 & 3 & 372 & 33.15 \\
\hline $\begin{array}{l}\text { Intermediate } \\
\text { thalassemia }\end{array}$ & 203 & 46 & 44 & 25 & 17 & 15 & 8 & 358 & 31.91 \\
\hline Thalassemia+Sickle & 76 & 19 & 22 & 8 & 8 & 7 & 2 & 142 & 12.65 \\
\hline Sickle cell anemia & 63 & 14 & 7 & 3 & 5 & 7 & 2 & 101 & 9 \\
\hline Bone marrow failure & 27 & 8 & 7 & 4 & 3 & 2 & 0 & 51 & 4.55 \\
\hline Minor thalassemia & 21 & 3 & 4 & 5 & 4 & 2 & 0 & 39 & 3.48 \\
\hline $\begin{array}{l}\text { Unknown bleeding } \\
\text { tendency }\end{array}$ & 9 & 4 & 2 & 2 & 0 & 1 & 0 & 18 & 1.52 \\
\hline Unexplained Anemia & 8 & 3 & 2 & 2 & 1 & 0 & 1 & 17 & 0.71 \\
\hline Sideroblastic anemia & 8 & 0 & 0 & 0 & 0 & 0 & 0 & 8 & 0.62 \\
\hline Haemophelia & 5 & 1 & 1 & 0 & 0 & 0 & 0 & 7 & 0.27 \\
\hline Immune hemolysis & 3 & 0 & 0 & 0 & 0 & 0 & 0 & 3 & 0.18 \\
\hline VWR & 2 & 0 & 0 & 0 & 0 & 0 & 0 & 2 & 0.09 \\
\hline Factor 8 Deficiency & 0 & 0 & 1 & 0 & 0 & 0 & 0 & 1 & 0.09 \\
\hline Severe G6PD & 1 & 0 & 0 & 0 & 0 & 0 & 0 & 1 & 0.09 \\
\hline $\begin{array}{l}\text { Myelodysplastic } \\
\text { syndrome }\end{array}$ & 0 & 1 & 0 & 0 & 0 & 0 & 0 & 1 & 0.09 \\
\hline $\begin{array}{l}\text { Major thalassemia } \\
\text { +G6PD }\end{array}$ & 0 & 0 & 0 & 0 & 0 & 1 & 0 & 1 & 1.6 \\
\hline Total & 633 & 154 & 148 & 69 & 61 & 41 & 16 & 1122 & $100 \%$ \\
\hline $\begin{array}{l}\text { \% (according to } \\
\text { area) }\end{array}$ & 56.42 & 13.73 & 13.19 & 6.15 & 5.44 & 3.65 & 1.43 & $100 \%$ & \\
\hline
\end{tabular}


Table 2: Gender distribution of HHD patients in Najaf Province.

\begin{tabular}{|l|c|c|c|c|c|c|c|}
\hline \multirow{2}{*}{ HHD } & \multicolumn{2}{|c|}{ Male } & \multicolumn{2}{c|}{ Female } & \multirow{2}{*}{ Total } & $\chi^{2}$ & \multirow{2}{*}{ p-value } \\
\cline { 2 - 8 } & Number & $\%$ & Number & $\%$ & & & \\
\hline Major thalassemia & 200 & 53.76 & 172 & 46.24 & 372 & 0.155 & 0.694 \\
\hline Intermediate thalassemia & 192 & 53.63 & 166 & 46.37 & 358 & 0.141 & 0.708 \\
\hline Thalassemia+Sickle & 76 & 53.52 & 66 & 46.48 & 142 & 0.129 & 0.719 \\
\hline Sickle cell anemia & 50 & 49.5 & 51 & 50.5 & 101 & 0.044 & 0.834 \\
\hline Bone marrow failure & 30 & 58.82 & 21 & 41.18 & 51 & 1.241 & 0.265 \\
\hline Minor thalassemia & 22 & 56.41 & 17 & 43.59 & 39 & 0.593 & 0.441 \\
\hline Unknown bleeding tendency & 15 & 64.71 & 3 & 35.29 & 18 & 3.865 & 0.049 \\
\hline Unexplained Anemia & 11 & 83.33 & 6 & 16.67 & 17 & 23.723 & $<0.001$ \\
\hline Haemophelia & 6 & 85.71 & 1 & 14.29 & 7 & 27.876 & $<0.001$ \\
\hline Sideroblastic anemia & 4 & 50 & 4 & 50 & 8 & 0 & 1 \\
\hline Immune hemolysis & 2 & 66.67 & 1 & 33.33 & 3 & 5.082 & 0.024 \\
\hline VWR & 1 & 50 & 1 & 50 & 2 & NA & NA \\
\hline Factor 8 Deficiency & 0 & 0 & 1 & 100 & 1 & NA & NA \\
\hline Severe G6PD & 0 & 0 & 1 & 100 & 1 & NA & NA \\
\hline Myelodysplastic syndrome & 10 & 54.37 & 512 & 45.63 & 1122 & 8.706 & 0.003 \\
\hline Major thalassemia +G6PD & 0 & 1 & 100 & 1 & NA & NA \\
\hline Total & 100 & 0 & 0 & 1 & NA & NA \\
\hline
\end{tabular}


Table 3: Blood group distribution of HHD patients in Najaf province.

\begin{tabular}{|l|c|c|c|c|c|c|c|c|c|}
\hline \multirow{2}{*}{ HHD } & \multicolumn{2}{|c|}{ A } & \multicolumn{2}{c|}{ AB } & \multicolumn{2}{c|}{ B } & \multicolumn{2}{c|}{ O } & \\
\cline { 2 - 10 } & $+\mathrm{Ve}$ & $-\mathrm{Ve}$ & $+\mathrm{Ve}$ & $-\mathrm{Ve}$ & $+\mathrm{Ve}$ & $-\mathrm{Ve}$ & $+\mathrm{Ve}$ & \multirow{2}{*}{$-\mathrm{Ve}$} & \\
\hline Major thalassemia & 110 & 12 & 27 & 1 & 85 & 9 & 113 & 15 & 372 \\
\hline Intermediate thalassemia & 112 & 6 & 22 & 3 & 68 & 3 & 136 & 8 & 358 \\
\hline Thalassemia+Sickle & 42 & 3 & 9 & 1 & 35 & 3 & 45 & 4 & 142 \\
\hline Sickle cell anemia & 26 & 2 & 5 & 0 & 24 & 3 & 39 & 2 & 101 \\
\hline Bone marrow failure & 11 & 1 & 3 & 0 & 12 & 2 & 22 & 0 & 51 \\
\hline Minor thalassemia & 9 & 0 & 0 & 0 & 10 & 0 & 18 & 2 & 39 \\
\hline Unexplained Anemia & 3 & 1 & 0 & 0 & 6 & 0 & 8 & 0 & 18 \\
\hline Sideroblastic anemia & 2 & 1 & 0 & 0 & 1 & 1 & 2 & 1 & 8 \\
\hline Hemophilia & 4 & 0 & 0 & 0 & 1 & 0 & 2 & 0 & 7 \\
\hline Immune hemolysis & 0 & 0 & 1 & 0 & 1 & 0 & 0 & 1 & 3 \\
\hline Unknown bleeding tendency & 6 & 2 & 1 & 0 & 5 & 0 & 4 & 0 & 18 \\
\hline \multicolumn{1}{|c|}{ Total } & 219 & 134 & 68 & 5 & 248 & 21 & 389 & 33 & 1117 \\
\hline Percentage \% & 29.10 & 2.51 & 6.09 & 0.45 & 22.20 & 1.87 & 34.83 & 2.95 & 100 \\
\hline
\end{tabular}


Table 4: The age distribution of all HHD patients in addition to major subgroups in Najaf province.

\begin{tabular}{|l|c|c|c|c|c|c|c|c|c|}
\hline Blood Disorders / Age yr. & $0-5$ & $5-10$ & $10-15$ & $15-20$ & $20-25$ & $25-30$ & $30-35$ & $35-40$ & $>40$ \\
\hline All HHD patients & 512 & 266 & 132 & 72 & 37 & 21 & 21 & 24 & 37 \\
\hline Major thalassemia & 208 & 87 & 36 & 19 & 6 & 2 & 7 & 3 & 4 \\
\hline Intermediate thalassemia & 148 & 84 & 41 & 25 & 13 & 9 & 9 & 10 & 19 \\
\hline Thalassemia+Sickle & 72 & 28 & 12 & 10 & 5 & 4 & 3 & 2 & 6 \\
\hline Sickle cell anemia & 29 & 29 & 24 & 6 & 7 & 1 & 1 & 2 & 2 \\
\hline Bone marrow failure & 24 & 13 & 6 & 4 & 0 & 2 & 0 & 0 & 2 \\
\hline
\end{tabular}




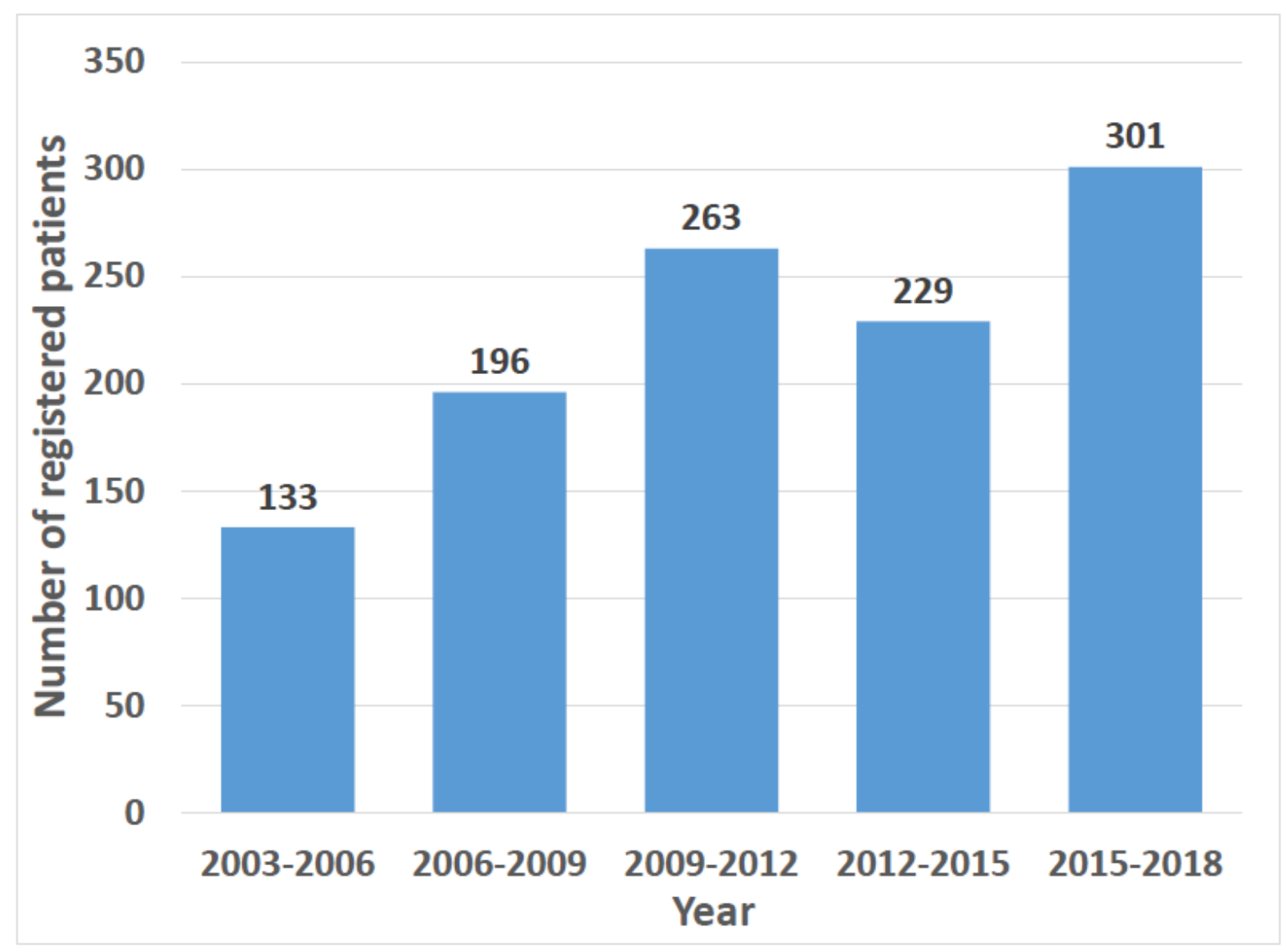

Figure 1: The total number of patients registered in the Thalassemia Unit-Najaf over the years from 2003 till the end of 2018. 


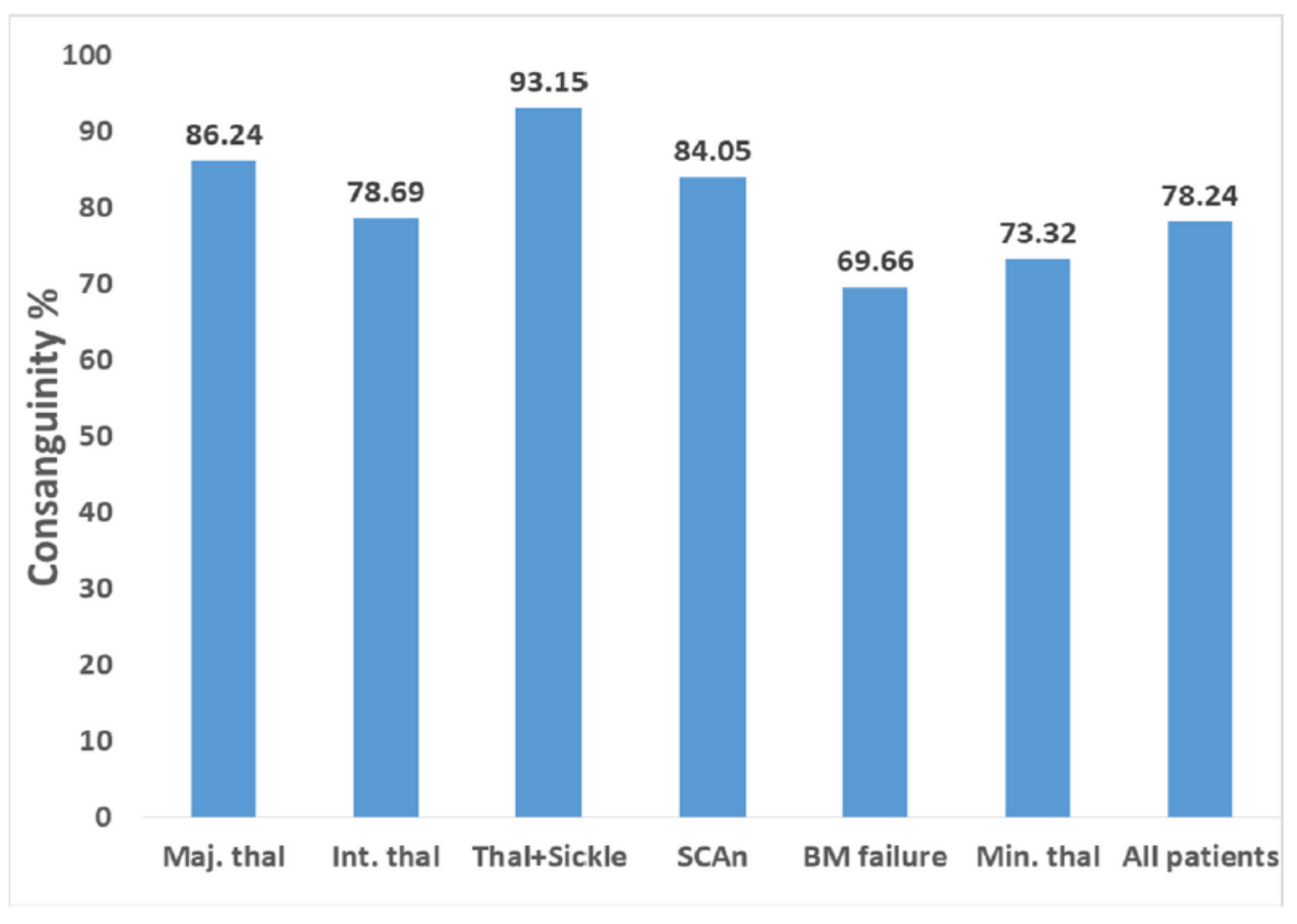

Figure 2: Consanguinity among patients with HHD in Najaf Province 